\title{
PERGESERAN PARADIGMA HUKUM PENGELOLAAN SUMBER DAYA AIR DAN PENGARUHNYA TERHADAP PENGAKUAN KELEMBAGAAN LOKAL BERDASARKAN PRINSIP KEADILAN (PERSPEKTIF SEJARAH HUKUM)
}

\section{Oleh :}

\author{
Jati Nugroho ${ }^{1}$
}

\begin{abstract}
Abstraksi
Paradigma hukum suatu negara sangat dipengaruhi oleh karakter pemegang kekuasaan, yang artinya kecenderungan responsif atau represif. Karakter politik otoriter dari aturan hukum mempromosikan hukum yang represif atau responsif. Paradigma bergeser seiring dengan perubahan politik di suatu negara yang memunculkan 4 (empat) paradigma terkait dengan pengelolaan sumber daya alam, yaitu: 1) Manajemen Sumber Daya Berbasis Negara, 2) Manajemen Sumber Daya Berbasis Masyarakat, 3) Manajemen Koperasi dan 4) Manajemen Sumber Daya Berbasis Pasar.

Pasal 33 ayat (2) dan ayat (3) Undang-Undang Negara Republik Indonesia tahun 1945 melalui hak untuk mengontrol negara atas air digunakan untuk kemakmuran terbesar rakyat. Prinsip pengelolaan sumber daya air, terutama air irigasi pertanian melalui institusi lokal sesuai dengan Pasal 18B ayat (2) Undang-Undang Dasar Negara Republik Indonesia Tahun 1945, kewajiban pemerintah daerah untuk mengakui dan menghormati kesatuan masyarakat hukum adat dan masyarakatnya. berbagai hak tradisional.

Pergeseran paradigma hukum dalam pengelolaan sumber daya air, terutama air irigasi, telah terjadi di Indonesia sejak orde lama, orde baru dan orde reformasi hingga diberlakukannya UU No. 17 tahun 2019 sangat dipengaruhi oleh hukum politik diadopsi. Di tingkat legislasi selalu ada hubungan antara UU Pemerintah Daerah dan UU Sumber Daya Air dan pengaruh budaya hukum masyarakat. Dalam hal itu, akan ada trade-off di antara mana hukum diutamakan atas apakah hukum negara bagian atau lokal melalui hukum adat. Jadi tentu saja negara juga mengakui keberadaan institusi lokal sebagai bentuk pengakuan pluralisme hukum sesuai dengan amanat konstitusi.
\end{abstract}

Kata Kunci : pergeseran paradigma hukum dalam pengelolaan sumber daya air, pengaruh pengakuan lembaga lokal, prinsip keadilan, perspektif Sejarah Hukum.

\section{Latar Belakang}

Paradigma $^{2}$ hukum yang dianut negara berkaitan erat dengan kebijakan dan model pembangunan selama pemerintahan dari orde lama, orde baru dan orde

Dosen LLDikti7 DPK Sekolah Tinggi Ilmu Hukum (STIH) Jenderal Sudirman Lumajang, email : thomasjatinugroho@gmail.com 
reformasi. Paradigma bergeser seiring dengan perubahan politik suatu negara memunculkan 4 (empat) paradigma berkaitan pengelolaan sumber daya alam, yaitu: 1) Pengelolaan sumber daya alam berbasis negara (State Based Resources Management (SBRM)), 2) Pengelolaan sumber daya alam berbasis pada komunitas (PSBK atau CBRM/Commmunity Based Resources Management), 3) Pengelolaan sumber daya alam Cooperative Management (co-management) dan 4) Pengelolaan sumber daya alam berbasis pasar (MBRM atau Market Based Resources Management). Paradigma hukum suatu negara sangat dipengaruhi oleh karakter pemegang kekuasaan artinya apa kecenderungan responsif atau represif. Menurut Nonet dan Selznick, karakter politik yang otoriter dilahirkan peraturan hukum tersebut mengedepankan hukum yang represif (repressive law). ${ }^{3}$

Campur tangan negara terhadap milik bersama (res commune) berupa air ditetapkan dalam ketentuan UUD NRI 1945, Pasal 33 ayat (2) dan ayat (3) melaui hak menguasai negara atas air dipergunakan untuk sebesar-besar kemakmuran rakyat. Prinsip pengelolaan sumber daya air terutama air irigasi pertanian melalui kelembagaan lokal menurut Pasal 18B ayat (2) UUD NRI 1945, maka ada kewajiban pemerintah daerah mengakui dan menghormati kesatuan masyarakat hukum adat (adat rechtsgemenschap) dan berbagai hak tradisionalnya (constitutional respect and recognition). ${ }^{4}$

Secara filosofis bahwa norma dalam konstitusi yang mengatur air terutama air irigasi pertanian dikuasai oleh negara harus diabdikan untuk kemakmuran rakyat

2 Paradigma berasal dari kata paradigm (Inggris) yang berarti contoh atau pola (Oxford English Dictionary), paradeigma (Yunani), para berarti disamping atau disebelah, dekynai, memperlihatkan model, contoh, tipe, ideal. Menurut Kuhn adalah seperangkat keyakinan orang atau perilaku orang (dalam hal ini dalam rangka bagaimana mengelola sumber daya air) yang memandu tindakan-tindakan ilmuwan baik dalam tingkah laku sehari hari maupun dalam penyelidikan ilmiah. Willarjo mengatakan paradigma adalah asumsi-asumsi dasar yang diyakini ilmuwan dan menentukan cara dia memandang gejala yang ditelaahnya yang mempengaruhi jalan pikir dan perilaku ilmuwan dalam berolah ilmu. Ilmu hukum mengalami transformasi paradigmatik dari order ke full disorder. Ilmu hukum tidak boleh tertinggal, menurut Hans Kelsen ilmu hukum digarap dan diikat dengan paradigma. Lihat Rachmad Safa'at, "Kumpulan Kuliah Paradigima Hukum Pluralistik", Program Doktor Ilmu Hukum UB Malang, 2016.

3 Phillips Nonet \& Phillips Selznick, Hukum Responsif, diterjemahkan dari Law and Society in Transition : Toward Responsif Law. Penerjemah Nurainun Mangunsong, Bandung, Nusa Media, 2013, hlm. 20.

4 Ketentuan dalam UUD 1945 diatur dalam Pasal 18 B ayat (2). Berikut kutipan lengkap pasal tersebut : Negara mengakui dan menghormati kesatuan-kesatuan masyarakat hukum adat beserta hak-hak tradisionalnya sepanjang masih hidup dan sesuai perkembangan masyarakat dan prinsip Negara Kesatuan Republik Indonesia, yang diatur dalam undang-undang. 
dengan berkeadilan dan memberi kemanfaatan. Negara harus memberikan kesejahteraan dan keadilan sosial. ${ }^{5}$

Secara yuridis, hak konstitusional rakyat atas sumber daya air yang diatur dalam Pasal 33 ayat (3), Pasal 28A, 28I ayat (1) dan Pasal 18 B ayat (2) UUD NRI 1945 yang tetap mengakomodasi dengan cara memperhatikan dan mengakui kelembagaan lokal harus tetap sesuai prinsip keadilan sosial. Konsekuensinya maka UU berkaitan sumber daya air tidak boleh bertentangan dengan konstitusi.

Secara historis, perubahan dalam pengaturan UU Sumber Daya Air yang menganut paradigma hukum berbeda-beda dimulai dari diberlakukannya masa orde lama melalui Algemeene Water Reglement 1936 hingga orde baru dengan UU No. 11 Tahun 1974. Selanjutnya dalam masa reformasi diberlakukannya UU No. 7 Tahun 2004 yang menganut paradigma pengelolaan sumber daya alam berbasis pasar (MBRM atau Market Based Resources Management). Namun ironisnya melalui Putusan Mahkamah Konstitusi RI, bulan Pebruari 2015 bahwa keberadaan Undang-Undang Nomor 7 Tahun 2004 tentang Sumber Daya Air bertentangan dengan UUD NRI Tahun 1945. Dengan tidak diberlakukannnya Undang-Undang Nomor 7 Tahun 2004 tentang Sumber Daya Air maka UndangUndang Nomor 11 Tahun 1974 tentang Pengairan dinyatakan berlaku kembali, padahal jelas-jelas keberadaan UU yang ditetapkan masa orde baru tersebut mengabaikan pluralisme hukum.

Dengan berlakunya Undang-Undang Nomor 17 Tahun 2019 tentang Sumber Daya Air maka diharapkan terjadi pergeseran paradigma hukum yang belaku sebelumnya yang selalu mengabaikan kelembagaan lokal agar sejalan dengan tujuan pembangunan hukum nasional dalam UU No. 17 Tahun 2007. Politik hukum dalam UU tersebut dirumuskan mengakomodir hukum tertulis dan tidak tertulis itu dilaksanakan dalam berbagai politik hukum yang melalui berbagai undang-undang.

Suteki, Rekonstruksi Politik Hukum Hak Atas Air Pro-Rakyat, (Malang: Surya Pena Gemilang Publishing, 2010), hlm. 143. Selanjutnya Suteki menyatakan bahwa makna keadilan individual adalah kehendak mikro yang pelaksanaannya tergantung kehendak pribadi, sedangkan keadilan sosial adalah keadilan makro yang pelaksanaannya tidak tergantung kehendak pribadi, tetapi sudah bersifat struktural sebagaimana diatur dalam Pasal 33 ayat (3) UUD NRI 1945. 
Keberadaan Undang-Undang Nomor 17 Tahun 2019 tersebut mengatur tentang prinsip syarat tertentu dalam pemberian izin pengusahaan air terhadap pihak swasta dan untuk air irigasi tidak diatur secara jelas pengakuan kelembagaan lokal pengelola irigasi. ${ }^{6}$ Dominasi pihak swasta terhadap negara dikhawatirkan dapat mengelabui pengelolaan sumber daya air termasuk irigasi dan kelembagaan lokalnya dengan dalih kerja sama dan tidak secara tegas mengakui keberadaan kelembagaan lokal. ${ }^{7}$

Secara sosiologis, eksistensi kelembagaan lojal pengelola irigasi khsusnya di Jawa oleh $u l u-u l u^{8}$ sejak masa orde baru dan masa reformasi bahkan sampai disahkannya UU No. 17 Tahun 2019 diintervensi hukum negara dengan cara kooptasi $^{9}$ dimana UU tersebut tidak secara tegas mengatur keberadaan kelembagaan lokal. Meski secara faktual kelembagaan lokal masih hidup dan berkembang namun hukum negara tidak mengakui keberadaan kelembagaan lokal secara penuh.

Hukum negara sekedar mengakui kelembagaan lokal dianggap mengakomodasi hukum lokal tercermin dari peraturan perundang-undangan yang mengatur air irigasi di tingkat Provinsi Jawa Timur. Pengakuan dalam konteks pluralisme hukum sebagai "weak legal pluralism”, hukum pengelolaan air irigasi lokal tradisional inferior, tidak mencerminkan keadilan. ${ }^{10}$

\section{Rumusan Masalah}

Rumusan masalah yang diangkat dalam penelitian ini adalah Apakah pergeseran paradigma hukum pengelolaan sumber daya air mampu mempengaruhi

$6 \quad$ Lihat Pasal 2 huruf f UU No. 17 Tahun 2019 bahwa Pengelolaan Sumber Daya Air dilakukan berdasarkan asas kearifan lokal. Dalam Penjelasan pasal tersebut dinyatakan bahwa yang dimaksud dengan asas "kearifan lokal" adalah bahwa dalam Pengelolaan Sumber Daya Air harus memperhatikan nilai-nilai luhur yang berlaku dalam tata kehidupan masyarakat. https://katadata.co.id/berita/2019/09/17/dpr-sahkan-ruu-sda-air-kini-sepenuhnya-dikuasai negara, diakses tanggal 9 Januari 2020.

8 Pasal 3 Keputusan Gubernur Jawa Timur Nomor 77 Tahun 1995 tentang Pembentukan dan Pembinaan HIPPA Provinsi Jawa Timur dinyatakan bahwa HIPPA sebagai organisasi bersifat sosial bertujuan meningkatkan kesejahteraan anggotanya dengan memperhatikan kepengurusan air tradisonal yang telah ada.

$9 \quad$ Kooptasi merupakan penerimaan unsur-unsur baru dalam kepemimpinan suatu organisasi sebagai salah satu cara untuk menghindari terjadinya kegoncangan dalam stabilitas organisasi yang bersangkutan.

Aristoteles menyatakan ada keadilan dalam masyarakat ketika: (1) seseorang tidak melanggar hukum yang berlaku, sehingga keadilan berarti "lawfull", yaitu hukum tidak boleh dilanggar dan aturan hukum harus ditaati; dan (2) seseorang tidak boleh lebih baik haknya, sehingga keadilan berarti persamaan hak (equal). 
pengakuan kelembagaan lokal berdasarkan prinsip keadilan (Perspektif Sejarah Hukum) ?

\section{Tujuan Penelitian}

Adapun tujuan yang hendak dicapai dalam penelitian ini adalah untuk mengetahui pergeseran paradigma hukum pengelolaan sumber daya air mampu mempengaruhi pengakuan kelembagaan lokal berdasarkan prinsip keadilan (Perspektif Sejarah Hukum).

\section{Manfaat Penelitian}

Hasil Penelitian ini, secara teoritis maupun praktis diharapkan dapat memberikan manfaat bagi akademisi atau peneliti hukum untuk mengembangkan ilmu pengetahuan dibidang hukum khususnya paradigma hukum pengelolaan sumber daya air.

\section{Metode Penelitian}

Metode pada penelitian ini menggunakan metode penelitian yuridisnormatif, yakni penelitian mengenai norma, baik itu berbentuk asas ataupun kaidah hukum serta peraturan perundang-undangan. ${ }^{11}$ Penelitian ini dilakukan dengan cara melakukan analisis pada peraturan perundang undangan tentang hukum pengelolaan sumber daya air.

Statute Approach atau pendekatan perundang undangan adalah pendekatan masalah yang digunakan di dalam penelitian ini. Pendekatan konseptual atau pendekatan melalui doktrin yang berkembang dalam ilmu hukum juga merupakan pendekatan yang dilakukan dalam penelitian ini. Yang mana doktrin tersebut berhubungan dengan permasalahan yang diteliti.

Bahan Hukum Primer atau Primary Sources yang digunakan dalam penelitian ini bersifat autoratif atau memiliki sifat otoritas. Yaitu peraturan perundang undangan serta aturan yang telah dibuat oleh legislatif. ${ }^{12}$ Undang Nomor 11 Tahun

11 Mukti Fajar dan Yulianto Achmad, 2010, Dualisme Penelitian Hukum Normatif dan Empiris, Yogyakarta: Pustaka Pelajar, hlm. 34

12 Soerjono Soekanto \& Sri Mamudji, 2015, Penelitian Hukum Normatif: Suatu Tinjauan Singkat, Jakarta: Rajawali Pers, hlm 33 
1974 tentang Pengairan, Undang-Undang Undang-Undang Nomor 7 Tahun 2004 tentang Sumber Daya Air, Undang-Undang Nomor 17 Tahun 2019 tentang Sumber Daya Air merupakan bahan hukum primer yang digunakan dalam penelitian ini.

Bahan Hukum Sekunder atau Secondary Sources pada penelitian hukum normatif dapat berupa buku hukum serta jurnal-jurnal hukum sebagai bahannya. Dimana buku buku tersebut berkaitan mengenai penelitian ini, yakni pergeseran paradigma hukum pengelolaan sumber daya air mampu mempengaruhi pengakuan kelembagaan lokal berdasarkan prinsip keadilan (Perspektif Sejarah Hukum).

Pada penelitian ini, Hal yang pertama dilakukan adalah dengan cara mengumpulkan bahan hukum primer serta sekunder. Ketika semuanya telah terkumpul maka data tesebut akan diolah secara sistematis dan dilakukan analisis untuk memperoleh kejelasan masalah yang sedang dikaji. ${ }^{13}$

\section{Pembahasan}

\section{A. Paradigma Hukum Pengelolaan Sumber Daya Alam Masa Orde Lama}

Struktur kelembagaan dalam sistem pemerintahan daerah dan desa ditata kembali dengan dikeluarkan UU Nomor 18 Tahun 1965 tentang Pokok-Pokok Pemerintahan Daerah dan UU Nomor 19 Tahun 1965 tentang Desapraja. Alat kelengkapan Desapraja sebagaimana ditentukan dalam Pasal 7 UU Nomor 19 Tahun 1965 terdiri atas: Kepala desa, Badan Musyawarah Desa, Pamong Desapraja, Panitera Desapraja, Petugas Desapraja dan Badan Pertimbangan Desapraja.

Khusus berkaitan dengan petugas Desapraja merupakan pembantupembantu Kepala Desapraja dan pamong desapraja melakukan sesuatu tugas tertentu dalam hal-hal bersangkutan dengan urusan agama, keamanan, pengairan atau lain-lain urusan rumah tangga desapraja menurut adat kebiasaan setempat. Petugas-petugas tersebut dengan nama seperti penghulu, khatib, modin, jagabaya, kebayan atau ulu-ulu diangkat dan diberhentikan

3 Mukti Fajar \&Yulianto Achmad, 2010, Dualisme Penelitian Hukum Normatif dan Empiris, Yogyakarta: Pustaka Pelajar, hlm. 160 
kepala desapraja dengan persetujuan Badan Musyawarah Desapraja (Bamudes). ${ }^{14}$

Penggunaan nama desapraja ${ }^{15}$ dalam UU tentang Desapraja memberikan istilah baru dalam Penjelasan UUD 1945 Pasal 18, kesatuan masyarakat hukum di berbagai wilayah Indonesia mempunyai nama asli beragam. Dengan keluarnya UU Nomor 19 Tahun 1965 warisan hukum yang berlaku seperti IGO dan IGOB serta peraturan pelaksanaannya tidak berlaku lagi.

Khusus berkaitan lembaga ulu-ulu desa, merupakan lembaga yang telah ada sejak sebelum jaman penjajahan Belanda. Keberadaan lembaga ulu-ulu berasal dari nama jabatan seorang pamong desa diserahi tugas mengurus masalah pengairan di desa terutama mengatur pembagian air ke sawah petani, mengorganisir gotong royong memelihara saluran dan bangunan pengairan, serta melakukan komunikasi dan melaporkan kepada Kepala Desa serta petugas pengairan.

Dari struktur kelembagaan organisasi pemerintahan desa jabatan meliputi: Kepala Desa, Carik, Kampung Polisi, Kampung Gawe, Tuwawa/ulu-ulu, Kebayan dan Modin di atas tampak bahwa petugas Desapraja yang telah diakui pada masa pemerintah kolonial Belanda berdasarkan hukum adat diadopsi masa orde lama dengan UU No. 19 Tahun 1965 dan lebih banyak petugas meliputi pembantu-pembantu Kepala Desapraja dan pamong desapraja yang melakukan tugas tertentu seperti penghulu, khatib, modin, jagabaya, kebayan atau ulu-ulu tetap diakui keberadaannya dengan mendapat gaji dari tanah bengkok desa.

Konstruksi hukum dan konstruksi sosial terhadap posisi dan fungsi Pamong Desa merupakan salah satu dimensi penting dalam penyelenggaraan pemerintahan desa adalah kewenangan yang dimiliki desa mengelola pemerintahan. Pada saat berlakunya IGO dan IGOB, urusan rumah tangga desa dibatasi hanya mengurus urusan fisik saja seperti pemakaian dan

14 Ni'matul Huda, Hukum Pemerintaha Desa Dalam Konstitusi Indonesia Sejak Kemerdekaan Hingga Era Reformasi, (Malang: Setara Press, 2015), hlm. 136-139.

15 Terdapat kesamaan antara pengaturan Inlandshe Gemeente Ordonantie dan Inlandshe Gemeente Ordonantie voor Buitengewesten dengan UU No. 19 Tahun 1965 dalam hal memandang desa sebagai sebuah kesatuan masyarakat hukum (volkgemeenschappen) memiliki hak ada istiadat dan asal usul. Diakses pada tanggal 9 Januari 2020 dari http://galihlike9.blogspot.co.id/2014/03/sejarah-perkembangan-desa-sesuai.html 
pemeliharaan pekerjaan umum desa menyangkut jalan, jembatan, saluran air, rumah, tanah, lapangan, pasar dan tempat penyimpanan air. ${ }^{16}$

Perkembangan hukum pengelolaan sumber daya air berkaitan dengan kelembagaan kearifan lokal di Indonesia dimulai sejak berlakunya Algemeene Water Reglement 1936 yang menganut 2 (dua) paradigma hukum pengelolaan sumber daya air khususnya sistem irigasi di Indonesia, yaitu pertama, paradigma pengelolaan yang didominasi oleh intervensi Pemerintah (disebut pola berwawasan teknis) dan kedua, paradigma yang didominasi oleh peran masyarakat setempat (disebut pola berwawasan sosial).

Pengakuan terhadap ulu-ulu juga dinyatakan dalam Algemeene Water Reglement (AWR) 1936 sebagai bentuk mengakomodasi keberadaan hukum yang hidup. Paradigma ini memberi peran individu dan masyarakat bukan hanya sebagai subjek melainkan juga sebagai aktor yang menetapkan tujuan, sebagai paradigma pengelolaan sumber daya alam yang berbasis masyarakat (community based resources management).

Paradigma bottom up yang sering disebut sebagai community based menurut Lawrence M. Friedman bahwa : “... welfare state, or more broadly, the welfare regulatory state. Basically, it is an active, interventionist state. Government is ubiquitous. "17 Bahwa kekuasaan Pemerintah berada dalam segala kehidupan masyarakat, sehingga Pemerintah dianggap merupakan jawaban atas segala permasalahan yang ada dalam kehidupan rakyat. Tindakan Pemerintah dalam negara kesejahteraan merupakan sebuah intervensi terhadap kehidupan rakyat.

\section{B. Paradigma Hukum Pengelolaan Sumber Daya Alam Masa Orde Baru}

Masa orde baru berorientasi pada pertumbuhan ekonomi dan industrialisasi bersumber pada ideologi dan paradigma modernisasi, yang menganggap "tradisi dan kearifan lokal yang melingkupi kehidupan masyarakat adat" merupakan suatu masalah dan menghambat pembangunan sehingga memaksakan paham modernisasi sebagai suatu keseragaman

http://kus.web.id/dilema-keberadaan-pamong-desa/

Lawrence M. Friedman, sebagaimana dikutip Satjipto Rahardjo, IImu Hukum, Citra Aditya Bakti, 2000, hlm. 13. 
(uniformitas) sistem sosial, ekonomi, politik, dan budaya yang melahirkan monokulturasi di hampir semua aspek dan bidang kehidupan masyarakat.

Awal Orde Baru ditandai dengan pengelolaan irigasi yang masih mengakui keberadaan lembaga $u l u-u l u$ dan mulainya model pengelolaan irigasi secara formal dalam wadah perkumpulan petani pemakai air (P3A) dampak dari keberhasilan Jawa Tengah dengan lembaga Dharma Tirta. Berkaitan dengan pengelolaan irigasi tersier yang dilakukan $u l u$-ulu maka sejak berlakunya UU Nomor 5 Tahun 1979.

Keberadaan UU No. 5 Tahun 1979 ini telah banyak mengubah struktur dan fungsi kelembagaan pemerintahah desa. Penyeragaman dan penyederhanaan struktur pemerintahah desa telah mengikis dan menggusur tatanan/adat istiadat, termasuk jabatan-jabatan di pemerintahan desa masa lalu. Misalnya istilah "lurah" pada masa lalu diganti dengan "kepala desa". Demikian pula istilah "carik" diganti dengan "sekretaris desa". Beberapa jabatan adat yang dahulu ada saai ini sudah dihapus, seperti kamituwa, bekel (kepala dukuh), ulu-ulu dan modin. ${ }^{18}$

Dalam pengelolaan irigasi diatur UU No. 11 Tahun 1974 melimpahkan wewenang pengelolaan irigasi dari pemerintah kepada badan-badan hukum tertentu, yang syarat-syaratnya diatur oleh Pemerintah, dengan menghormati hak-hak masyarakat hukum adat setempat dan kepentingan nasional. Paradigma yang dianut pada masa ini adalah Berbasis Negara (State Based Resources Management (SBRM)).

Hukum mengabdi kepada kekuasaan represif dan tata tertib yang represif pula terbukti kewajiban berbadan hukum bagi HIPPA (Himpunan Petani Pemakai Air) karena kearifan lokal tumbuh dan berkembang tanpa formalitas hukum. Kekuasaan yang memerintah adalah represif.

Kondisi yang demikian dijelaskan Penjelasan Umum Peraturan Pemerintah Nomor 23 Tahun 1982 tentang Irigasi, bahwa penggunaan air dengan dengan ijin ditujukan untuk semua yang mengusahakan air termasuk untuk keperluan pertanian. Pengurusan irigasi dapat dikecualikan tidak

18 Didk G Suharto,Membangun Kemandirian Desa (Perbandingan UU No. 5/1979, UU No. 22/1999, \& UU No. 32/2004 serta Perspektif UU No. 6/2014),Op.Cit., hlm. 194 
dilakukan pemerintah daerah, tetapi oleh suatu badan hukum tertentu yaitu perkumpulan petani pemakai air (P3A).

Hukum yang dibuat di atas menunjukkan keseragaman (legal uniformity) diberlakukan terhadap organisasi perkumpulan petani pemakai air (P3A) menurut Peraturan Daerah Jawa Timur Nomor 15 Tahun 1986 tentang irigasi di Jawa Timur (sekarang diubah menjadi Perda Provinsi Jawa Timur No. 6 tahun 2003), maka Gubernur Jawa Timur menetapkan pembentukan P3A dengan nama HIPPA (Himpunan Petani Pemakai Air).

Dengan diberlakukan organisasi perkumpulan petani pemakai air (P3A) menurut Peraturan Daerah Jawa Timur Nomor 15 Tahun 1986 tentang irigasi di Jawa Timur maka Gubernur Jawa Timur menetapkan pembentukan P3A dengan nama HIPPA (Himpunan Petani Pemakai Air). HIPPA sebagai wadah secara organisatoris, teknis dan finansial memelihara jaringan irigasi di tingkat usaha tani dengan memperhatikan kepengurusan tradisional yang telah ada.

Implementasi paradigma pembangunan berbasis negara kemudian diiringi kebijakan pembangunan instrumen hukum yang bercorak represif, mengabaikan hak-hak masyarakat dan menggusur keberadaan hukum yang hidup (living law) dalam masyarakat.

\section{Paradigma Hukum Pengelolaan Sumber Daya Alam Masa Orde Reformasi dan Pasca Putusan Mahkamah Konstitusi}

Seiring tuntutan orde reformasi persoalan irigasi yang dulu hanya bertumpu pada pembangunan infrastruktur saat ini ditinggalkan. Pembangunan kebijakan baru dalam pengelolaan SDM dalam pembangunan dan pengelolaan irigasi dengan mengadopsi pemikiran yang menganggap manusia sebagai konsep berbasis modal manusia atau human capital.

Dalam konferensi air dan lingkungan internasional yang diselenggarakan tahun 1992 di Dublin Irlandia, dicetuskan The Dublin Statement on Water and Sustainable Development (Dublin Principles) dimana Indonesia juga turut meratifikasinya. Salah satu dari prinsip dalam Dublin Principles itu adalah "water has an economic value in all itscompeting uses and should be recognized as an economic good". Prinsip ini telah mengubah paradigma 
terhadap air yang sebelumnya dianggap sebagai barang sosial menjadi barang ekonomi yang semuanya diserahkan kepada pasar.

Munculnya air sebagai barang ekonomi tidak terlepas dari pengaruh resep ekonomi neoliberal yang dipelopori oleh Amerika Serikat dan Inggris. Resepresep ekonomi neoliberal dibawa bertumpu pada kebijakan privatisasi, deregulasi dan liberalisasi yang mulai dijalankan di beberapa negara. Intervensi negara telah menyebabkan pasar tidak bisa bekerja dengan baik maka harus diubah menjadi pengelolaan sumbar daya alam berbasis pasar (Market Based Resources Management).

Struktur Kelembagaan, diterbitkannya UU No. 32 Tahun 2004 tentang Pemerintahan Daerah (LN No. 125 - 2004) menggantikan posisi UU No. 22 Tahun 1999. Secara implementatif, kehadiran UU No. 32 Tahun 2004 tidak banyak membawa perubahan. Pembangunan dengan sistem yang sentralistik, dari atas ke bawah, dipandang sebagai sebuah kegagalan, dan membuat ketergantungan masyarakat, terutama masyarakat desa. Lahirnya UndangUndang Nomor 6 Tahun 2014 tentang Desa (LN No. 7 - 2014), membawa angin segar bagi pemerintahan desa, desa diposiskan sebagai subjek, bukan lagi objek pembangunan yang lebih mandiri dan memperhatikan kearifan lokal.

Pasal 1 UU No. 6 Tahun 2014 mendefinisikan Desa sebagai desa dan desa adat atau yang disebut dengan nama lain, merupakan kesatuan masyarakat hukum $^{19}$ yang memiliki batas wilayah yang berwenang untuk mengatur dan mengurus urusan pemerintahan, kepentingan masyarakat setempat berdasarkan prakarsa masyarakat, hak asal usul, dan/atau hak tradisional yang diakui dan dihormati dalam sistem pemerintahan Negara Kesatuan Republik Indonesia.

Sesuai dangan UU No. 7 Tahun 2004 pelaksanaan pengembangan dan pengelolaan irigasi harus dilakukan secara partisipatif. Dengan ditetapkannya

Penjelasan Mahkamah Konstitusi yang merupakan ringkasan dari penjelasan Ter Haar yang dimaksud kesatuan masyarakat hukum adat sebagaimana diatur dalam Pasal 18 B ayat (2) adalah, kesatuan masyarakat hukum adat adalah kelompok-kelompok teratur yang sifatnya ajeg dengan pemerintahan sendiri yang memiliki bendabenda materiil dan immaterial, yang memiliki ciri-ciri: a. Adanya kelompok-kelompok teratur; b. Menetap di suatu wilayah tertentu; c. Mempunyai pemerintahan sendiri; d. Memiliki benda-benda materiil dan immaterial. 
PP No. 77 Tahun 2001, keberadaan kelembagaan pengelola irigasi tradisional seperti subak dan $u l u-u l u^{20}$ menjadi lebih diakui karena dinyatakan dengan tegas dalam peraturan. Peraturan tersebut bahkan menegaskan bahwa perkumpulan merupakan wadah bagi petani pemakai air dalam suatu daerah pelayanan irigasi yang dibentuk oleh petani secara demokratis, termasuk kelembagaan lokal pengelola irigasi.

Dari hal di atas menunjukkan keberadaan ulu-ulu menunjukkan penggunaan paradigma pengelolaan sumber daya alam berbasis masyarakat (community base resources management) dapat memberikan saluran aspirasi dan ruang partisipasi masyarakat pengguna sumberdaya dengan kearifan lokalnya. Dengan ditetapkannya PP No. 77 Tahun 2001 dan PP No. 20 Tahun 2006, keberadaan kelembagaan pengelola irigasi tradisional seperti subak dan ulu-ulu diakui serta Pasal 1 UU No. 6 Tahun 2014 yang memberi ruang berdasarkan prakarsa masyarakat, hak asal usul, dan/atau hak tradisional yang diakui dan dihormati dalam sistem pemerintahan Indonesia.

Dalam perkembangan berikutnya keberadaan UU No. 7 Tahun 2004 oleh Mahkamah Konstitusi (MK) dibatalkan keberlakuan secara keseluruhan Undang-Undang Nomor 7 Tahun 2004 tentang Sumber Daya Air (SDA) karena tidak memenuhi enam prinsip dasar pembatasan pengelolaan sumber daya air. ${ }^{21}$ Hal lain yang dipertimbangkan MK, terkait prinsip "penerima manfaat jasa pengelolaan sumber daya air wajib menanggung biaya pengelolaan" harus dimaknai sebagai prinsip yang tidak menempatkan air sebagai objek untuk dikenai harga secara ekonomi. Dengan demikian, tidak ada harga air sebagai komponen penghitungan jumlah yang harus dibayar oleh penerima manfaat. Di samping itu, prinsip ini harus dilaksanakan secara fleksibel dengan tidak mengenakan perhitungan secara sama tanpa mempertimbangkan macam pemanfaatan sumber daya air. Oleh karena itu,

20 Bandingkan dengan masa Orde Baru, hampir semua kewenangan dalam pembangunan dan pengelolan irigasi dimiliki pemerintah pusat. Meskipun pembangunan irigasi dilakukan berbasis pembangunan insfrastruktur, tetapi secara normatif masalah pembinaan masyarakat mulai menjadi perhatian pemerintah. 
petani pemakai air, pengguna air untuk keperluan pertanian rakyat dibebaskan dari kewajiban membiayai jasa pengelolaan sumber daya air. ${ }^{22}$

\section{Pasca Disahkan UU No. 17 Tahun 2019 tentang Sumber Daya Air}

Paradigma yang akan dianut dengan disahkannnya UU No. 17 Tahun 2019 adalah memperbaiki paradigma sebelumnya yang tidak sesuai dengan harapan rakyat. Agar tidak terjadi loncatan dalam kewenangan pengelolaan sumberdaya dan dengan harapan akan terwujud dalam sebuah system pengelolaan sumberdaya yang lebih efektif dan efisien, maka konsep pengelolaan cooperative management (co-management). Ko-manajemen adalah sistem pengelolaan secara bersama antara masyarakat lokal dengan pemerintah.

Hal itu ditunjukkan pada ketentuan Pasal 7 UU SDA menyatakan bahwa pada prinsipnya airr tidak dapat dimiliki dan/atau dikuasai oleh perseorangan, kelompok masyarakat, atau badan usaha. Hal ini sejalan dengan Pasal 33 ayat (3) UUD NRI 1945. Namun demikian untuk pengakuan Hak Ulayat Masyarakat Adat, termasuk hak yang serupa dengan itu dipahami bahwa yang dimaksud dengan Masyarakat Adat adalah sekelompok orang yang terikat oleh tatanan hukum adatnya sebagai warga bersama suatu persekutuan hukum adat yang didasarkan atas kesamaan tempat tinggal atau atas dasar keturunan.

Hak Ulayat Masyarakat Adat dianggap masih ada apabila memenuhi tiga unsur, yaitu; a) unsur Masyarakat Adat, b) unsur wilayah, dan c) unsur hubungan antara masyarakat tersebut dan wilayahnya, yaitu terdapat tatanan hukum. Pengakuan bersyarat dalam UU No. 17 Tahun 2019 ini pada hakikatnya merupakan bentuk pengakuan semua dan menunjukkan pengakuan hukum yang lemah (weak legal pluralism) dari hukum negara terhadap kelembagaan lokal berupa ulu-ulu berdasarkan hukum adat tidak pernah diatur. UU ini justru lebih lemah dibandingkan dengan UU No. 7 Tahun 2004 sebelumnya dalam hal pengakuan kelembagaan lokal.

Dengan demikian harapan untuk mencapai keadilan seperti yang akan dituju pada ketentuan Pasal 2 UU SDA bahwa Pengelolaan Sumber Daya Air dilakukan secara merata ke seluruh lapisan masyarakat di wilayah tanah Air

22 http://www.mahkamahkonstitusi.go.id/index.php?page $=$ web. Berita\&id $=10634$ 
sehingga setiap warga negara berhak memperoleh kesempatan yang sama untuk berperan dalam Pengelolaan Sumber Daya Air dan menggunakan Sumber Daya Air, maka tidak akan tercapai.

Implementasi paradigma pembangunan berbasis negara kemudian diiringi kebijakan pembangunan instrumen hukum yang bercorak represif, mengabaikan hak-hak masyarakat dan menggusur keberadaan hukum yang hidup (living law) dalam masyarakat. Selanjutnya dijelaskan Sudjito, paradigma hukum pengelolaan irigasi di Indonesia memang telah dijalankan, tetapi telah meninggalkan moralitas, artinya hukum telah diceraikan dari moralitasnya. Hukum yang berjalan saat ini lebih banyak berpihak pada penguasa, pengusaha, dan politisi, serta semakin memarjinalkan rakyat. Padahal yang dibutuhkan oleh rakyat adalah keadilan substansial dan keadilan sosial yang berdasarkan Ketuhanan Yang Maha Esa, bukan keadilan dari proses tawar-menawar dan pemberlakuan hukum formal. ${ }^{23}$

Paradigma yang salah ini menjelma menjadi serangkaian kebijakan dan program kerja yang sangat kapitalistik berupa privatisasi air, seiring dengan adanya tekanan dari Bank Dunia. Akibatnya pengelolaan air bersih yang seharusnya dikuasai oleh negara diserahkan kepada pihak swasta untuk tujuan komersial. Dengan demikian UU ini masih berparadigma berbasis pasar (MBRM atau Market Based Resources Management).

UU SDA tak hanya memberi peluang bagi hadirnya privatisasi sektor penyediaan air minum dan penguasaan sumber-sumber air (baik air tanah, air permukaan, maupun air sungai) secara komersial oleh badan usaha dan individu, namun juga penguasaan asing. Akibatnya pengelolaan air bersih yang seharusnya dikuasai oleh negara diserahkan kepada pihak swasta untuk tujuan komersial.

Hal itu nampak dari ketentuan Pasal 46 UU SDA yang mengatur tentang prinsip syarat tertentu dalam pemberian izin pengusahaan air terhadap pihak swasta. Dominasi pihak swasta terhadap negara dikhawatirkan dapat mengelabui dengan kedok kerja sama. Padahal dalam Putusan MK bernomor

Sudjito, "Refleksi Kebangsaan: Tinjauan Kehidupan Berbangsa Masa Kini dan ke Depan", Makalah disampaikan pada Seminar Nasional yang diselenggarakan Fakultas Peternakan UGM, pada tanggal 29 Desember 2011. 
85/PUU-XI/2013, MK menyatakan jaminan negara sebagai pemegang hak penguasaan atas air tidak dapat ditiadakan karena SDA merupakan bagian dari hak asasi bagi masyarakat. Sehingga hak penguasaan terhadap pengelolaan air tidak bisa dipegang seluruhnya oleh swasta.

\section{Kesimpulan}

Pergeseran paradigma hukum pengelolaan sumber daya air terutama air irigasi di Indonesia dalam perspektif sejarah hukum dimulai orde lama, orde baru dan orde reformasi hingga disahkannya UU No. 17 Tahun 2019 sangat dipengaruhi politik hukum yang berimplikasi pada UU Pemerintahan Daerah dan UU Sumber daya Air serta pengaruh budaya hukum masyarakat yang tercermin dengan kelembagaan lokal sebagai manifestasi hukum adat nampak sbb.:

a) Orde Lama, paradigma pengelolaan sumber daya air berbasis pada komunitas (Commmunity Based Resources Management), dipengaruhi politik hukum dari Algemeene Water Reglement (AWR) dan UU No. 19 Tahun 1965. Hukum negara mengakomodasi keberadaan kelembagaan lokal dalam pengelolaan air irigasi sehingga mencerminkan prinsip keadilan. Kelembagaan pengelolaan irigasi memberi ruang kepada kelembagaan lokal (ulu-ulu) mengelola irigasi dengan pembagian air berdasar keadilan distributif.

b) Orde Baru, paradigma pengelolaan sumber daya alam berbasis negara (State Based Resources Management) dipengaruhi politik hukum menekankan pertumbuhan ekonomi sehingga hukum negara menjadi otoritas negara dan mengabaikan kemajemukan hukum serta budaya hukum masyarakat yang turun-temurun. Melalui wadah tunggal organisasi formal melalui HIPPA tidak sesuai prinsip keadilan. Akibatnya daya laku UU No. 11 Tahun 1974 dan peraturan pelaksananya serta UU No. 5 Tahun 1979 yang diperankan HIPPA tidak efektif.

c) Orde Reformasi pengelolaan sumber daya alam berbasis pasar(Market Based Resources Management) dengan politik hukum lebih kepada profit oriented, komersialisasi, privatisasi sumber daya air dan petani harus 
membayar iuran pelayanan irigasi. Pasca Putusan MK yang kembali ke UU No. 11 Tahun 1974 dengan politik hukum mengabaikan kemajemukan hukum yang tumbuh dan berkembang, struktur kelembagaan HIPPA tidak mencerminkan keadilan sosial seperti amanat alinea ke-4 Pembukaan UUD NRI 1945 dan Pasal 33 ayat (3) UUD NRI 1945, dan

d) Pasca berlakunya UU No.17 Tahun 2019, merupakan bentuk pengakuan semua dan menunjukkan pengakuan hukum yang lemah (weak legal pluralism) dari hukum negara terhadap kelembagaan lokal berupa $u l u-u l u$ berdasarkan hukum adat tidak pernah diatur. Padahal yang dibutuhkan oleh rakyat adalah keadilan substansial dan keadilan sosial bukan keadilan dari proses tawar-menawar dan pemberlakuan hukum formal.

Selanjutnya peraturan perundang-undangan terutama peraturan pelaksana berkaitan sumber daya air terutama irigasi harus mencerminkan prinsip keadilan yang dijiwai nilai-nilai Pancasila. Pilihan paradigma hukum pengelolaan alam yaitu Cooperative Management sehingga pengelolaan sumber daya air terpadu dan berkelanjutan serta adanya keseimbangan kepentingan negara, rakyat dan dunia usaha. 


\section{DAFTAR PUSTAKA}

\section{Buku}

Bur Rasuanto. Keadilan Sosial (Pandangan Deontologis Rawls dan Habermas). Jakarta: Gramedia Pustaka Utama, 2005.

Didik G. Suharto.Membangun Kemandirian Desa (Perbandingan UU No. 5/1979, UU No. 22/1999, \& UU No. 32/2004 serta Perspektif UU No. 6/2014), Yogyakarta: Pustaka Pelajar, 2016.

Effendi Pasandaran. Irigasi di Indonesia, Strategi dan Pengembangan. Jakarta: LP3ES, 1991.

Gerald Turkel.Law and Society: Critical Approaches. Boston: Allyn \& Bacon., 1996.

Hans Kelsen.General Theory of Law and State. New York : Russel and Russel, 1971. diterjemahkan oleh Raisul Mustaqiem, Teori Umum tentang Hukum dan Negara. Bandung : Nusamedia.

Jazim Hamidi.Hermeneutika Hukum : Teori Penemuan Hukum baru Dengan Interpretasi Teks. Yogyakarta : UII Press, 2005.

John Rawls.A Theory of Justice. Cambridge, Massachusett: Harvard University Press, 1995.diterjemahkan oleh Uzair Fauzan dan Heru Prasetyo.Teori Keadilan Dasar-Dasar Filsafat Politik untuk Mewujudkan Kesejahteraan Sosial Dalam Negara.Yogyakarta: Pustaka Pelajar, 2006.

Moh. Mahfud MD.Politik Hukum di Indonesia. Jakarta: LP3ES, 1998.

Ni'matul Huda.Hukum Pemerintaha Desa Dalam Konstitusi Indonesia Sejak Kemerdekaan Hingga Era Reformasi.Malang: Setara Press, 2015.

Rachmad Safa'at. Rekonstruksi Politik Hukum Pangan dari Ketahanan Pangan Ke Ketahanan Pangan. Malang: UB Press, 2013.

“Kumpulan Kuliah Paradigma Hukum Pluralistik", Program Doktor Ilmu Hukum UB Malang, 2016.

Sally Falk Moore.Law and Sosial Change : The Semi Autonomous Sosial Field as An Approprite Subject of Study. London: Routledge \& Kegan, 1986.

Satjipto Rahardjo. Ilmu Hukum. Bandung: Citra Aditya Bakti, 2000. 
Soeryono Soekanto.Pendekatan Sosiologi Terhadap Hukum. Bandung: Alumni, 1983.

Soetandyo Wigjosoebroto. Hukum Paradigma, Metode dan Dinamika Masalahnya. Jakarta: Elsam dan Huma, 2002.

Sudjito. "Hukum Pengelolaan Irigasi: Suatu Percobaan Untuk Melakukan Pengaturan Secara Holistik".Disertasi Program Doktor Ilmu Hukum Universitas Diponegoro Semarang, 2005.

Suteki. Rekonstruksi Politik Hukum Hak Atas Air Pro-Rakyat. Malang: Surya Pena Gemilang Publishing, 2010.

\section{Jurnal}

John Griffiths. "What is Legal Pluralism”, dalam Journal of Legal Pluralism and Unofficial Law, Number 24/1986.The Foundation for Journal of Legal Pluralism, 1986.

Sudjito."Studi Hukum Kritis terhadap Privatisasi Air Dalam Kerangka Hak Asasi Manusia", Mimbar Hukum, edisi khusus, No.44/VI/2003, Fakultas Hukum Universitas Gadjah Mada Yogyakarta, 2003.

\section{Internet}

http://kus.web.id/dilema-keberadaan-pamong-desa/ http://galihlike9.blogspot.co.id/2014/03/sejarah-perkembangan-desa-sesuai.html http://kus.web.id/dilema-keberadaan-pamong-desa/ https://katadata.co.id/berita/2019/09/17/dpr-sahkan-ruu-sda-air-kini sepenuhnyadikuasai-negara,

http://kus.web.id/dilema-keberadaan-pamong-desa/ http://www.mahkamahkonstitusi.go.id/index.php?page=web.Berita\&id=10634 